\title{
Quantitative Flow Cytometry Assessment of Feline Circulatory Breast Cancer Stem Cells
}

\author{
RashaH.Elsabagh ${ }^{1,2}$, HaithemA.M.Farghali $^{3}{ }^{*}$,IbrahimA.Emam ${ }^{3}$, Eman Ragab $^{2}$,Abdelfattah \\ A. Nada ${ }^{4}$, Salah A. Selim ${ }^{2 *}$
}

\begin{abstract}
${ }^{1}$ Animal Health Research Institute (AHRI), Shibin El-Kom Lab, Agriculture Research Centre, 32518 El-Monofiya, Egypt; ${ }^{2}$ Department of Microbiology, Faculty of Veterinary Medicine, Cairo University, 12211 Giza, Egypt; ${ }^{3}$ Department of Surgery, Anesthesiology and Radiology, Faculty of Veterinary Medicine, Cairo University,12211 Giza, Egypt; ${ }^{4}$ Animal Health Research Institute (AHRI), Agriculture Research Centre, 12618 Dokki, Egypt.
\end{abstract}

\begin{abstract}
The upsurge need for a rapid and accurate prognostic system for feline mammary neoplasia is crucial, as almost $90 \%$ of mammary tumors in cats tend to metastasize. Here, appears the importance of circulatory cancer biomarkers (liquid biopsies) such as circulating tumor cells (CTCs) and their subpopulation circulating cancer stem cells (cCSCs) as an effective, feasible, repeatable, and non-invasive tool for tumor prognosis and treatment monitoring. In the current prototype study, we detected and enumerated the circulatory breast cancer stem cells (BCSCs) for the first time in the feline peripheral blood by using the flow cytometer analysis (FCA) against their specific cellular markers $\left(\mathrm{CD} 44^{+} / \mathrm{CD} 24^{-}\right.$and $\left.\mathrm{CD} 133^{+}\right)$. In addition, we calculated Area Under the Curve (AUC), like hood ratios and cutoff points by statistical analysis. The results revealed statistically significant differences $(p<0.0001)$ between healthy and diseased animal groups with an excellent AUC value $(0.902$ for CD44 /CD24- cells and 0.990 for CD133+ population) that supported the use of FCA as a sensitive, specific, and rapid diagnostic and monitoring tool for mammary carcinoma. We also set up a cutoff value of diagnostic significance $\left(>276\right.$ for $\mathrm{CD} 44^{+} / \mathrm{CD} 24^{-}$populations and $>12$ for CD133+ cells).
\end{abstract}

Keywords | Feline mammary tumor; Cancer Biomarkers; Tumor Stem Cells; CD133+; CD44+/CD24-, Flow cytometer.

Received | September 30, 2021; Accepted | November 05, 2021; Published | November 15, 2021

*Correspondence | Salah A. Selim, Haithem A. M. Farghali, Department of Microbiology, Faculty of Veterinary Medicine, Cairo University, 12211 Giza, Egypt; Department of Surgery, Anesthesiology and Radiology, Faculty of Veterinary Medicine, Cairo University,12211 Giza, Egypt; Email: dr.salahselim@hotmail.com; dr_Haithem0@yahoo.com

Citation | Elsabagh RH, Farghali HAM, Emam IA, Ragab E, Nada AA, Selim SA (2021). Quantitative flow cytometry assessment of feline circulatory breast cancer stem cells. Adv. Anim. Vet. Sci. 9(12): 2201-2215.

DOI | http://dx.doi.org/10.17582/journal.aavs/2021/9.12.2201.2215

ISSN (Online) | 2307-8316; ISSN (Print) | 2309-3331

Copyright (c) 2021 Farghali et al. This is an open access article distributed under the Creative Commons Attribution License, which permits unrestricted use, distribution, and reproduction in any medium, provided the original work is properly cited.

\section{INTRODUCTION}

S pontaneous mammary tumors are one of the most common malignancies in cats. Almost $90 \%$ of the feline mammary carcinomas (FMC) are malignant, and they tend to metastasized and spread to the lungs and lymph nodes (Karabolovski et al., 2015). The WHO proposed female cats with naturally developed mammary tumors as an excellent model for studying breast carcinoma in human neoplasia. As feline shares many epidemiological, clinical, and morphological similarities with human breast cancer besides their shorter lifespan and the faster progression that provides a quicker gathering of data and trial accomplishment (De Las Mulas et al., 2000; Cannon, 2015).

The diagnosis, prognosis, and monitoring of therapeutic antitumor activity are mainly dependent on immunological examination or pathological features with histopathological investigations (Zappulli et al., 2015). The former techniques require repeatable tumor tissue biopsies for 
diagnosis, which are not feasible in all tumorigenic stages due to the critical sites of some tumors (Kazarian et al., 2017). As these procedures are time and effort-consuming, the early diagnosis of mammary tumors, employing serum/ plasma biomarkers, seems crucial for the patient's future (Kaszak et al., 2018). The serial analysis of liquid tumor biopsies is the best non-invasive, easily accessible method for breast cancer prediction, diagnosis, and prognosis (Duffy et al., 2018; Nicolini et al., 2018). Circulating Tumor Cells (CTCs) and their subpopulation Cancer Stem Cells (CSCs) were introduced by immense clinicians as an important prognostic marker for cancers, including Breast Cancer (BC). Being limited to the live tumor, unlike circulatory tumor DNA, gives CTCs prevalence over other blood biomarkers as they are illustrative for active tumor loci (Lopresti et al., 2019). Also, these cells can escape lysis by natural killer (NK) cells, survive in the bloodstream and resist apoptosis which support their metastatic abilities (Labelle et al., 2011; Freeman et al., 2015; Wu et al., 2017). These informations strongly supported that CTCs enumeration can be used as a prognostic index for patient overall survival rate. In humans, the cutoff value $\geq 5$ cells per $7.5 \mathrm{~mL}$ of whole peripheral blood (PB) is a consolidated prognostic factor with strong metastatic potentials and poor clinical outcomes (Wu et al., 2017).

Since 2003, many studies have supported the role of breast cancer stem cells (BCSCs( or tumor-initiating cells (TICs) in metastasis mediation, tumor recurrence, and resistance of chemo and radiotherapies after Al-Hajj et al. used $\mathrm{CD} 44^{+} / \mathrm{CD} 24^{-}$surface markers combination for the first isolation of BCSCs (Al-Hajj et al., 2003; Sayed et al., 2016; Mansoori et al., 2017).

The cancer cell can acquire stemness during Epithelial-Mesenchymal Transition (EMT) by up-regulation of CD44v, ALDH, CD133, and epithelial cell adhesion molecule (EpCAM) and downregulation of CD24 and E-cadherin (E-cad), together with co-expression of epithelial markers (cytokeratins $(\mathrm{CKs}))$ and mesenchymal markers (calponin (CALP)) (Jaggupilli and Elkord, 2012; Khoo et al., 2016; Granados-Soler et al., 2018). Breast neoplasia with high expression of $\mathrm{CD} 44^{+} / \mathrm{CD} 24^{- \text {llow }}$ is associated with boosted invasion and metastasis and localized at the tumor's invasive front (Baba and Câtoi, 2007; Liu et al., 2014). In comparison, those with high levels of CD133+ are associated with more aggressive and resistant tumor behavior and restricted deeply to intratumor hypoxic regions (Brugnoli et al., 2019).

Many previous studies that had been performed on companion animals have reported the identification and isolation of BCSCs. In felines and canines, TICs were identified and isolated by mammosphere formation, decrease
ALDH1 enzyme activity, or cell surface markers (CD44, $\mathrm{CD} 24$, and CD133) either from spontaneous mammary carcinoma (Barbieri et al., 2012, 2015) or mammary carcinoma cell lines (Michishita et al., 2013; Pang et al., 2013).

Similar to humans, the isolated canine and feline BCSCs were invasive with a high potential for mammosphere formation, exhibited epithelial-mesenchymal transition (EMT) phenotype, and showed resistance to chemotherapy drugs and radiation (Pang et al., 2013; Barbieri et al., 2015). These proliferative and aggressive cancer cells showed a promising treatment response by nanoparticles (Gold nanoparticles (GNPs), silver nanoparticles (Ag$\mathrm{NPs}$ )) in many previous studies in humans as well as felines (Ali et al., 2016; Sameen et al., 2020; Jabir et al., 2021; Jawad et al., 2021).

Because $\mathrm{cBCSC}$ are a rare subpopulation in $\mathrm{PB}$, their isolation and identification represent a real challenge (Yang, Imrali and Heeschen, 2015). As of now, there are two techniques to isolate potential BCSCs depending on their specific surface markers: either by fluorescence-activated cell sorting (FACS) or magnetic-activated cell sorting (MACS) (Akbarzadeh et al., 2019). The Flow Cytometer Analysis (FCA) is the most accurate, sensitive, and definitive laboratory tool for recognizing sporadic cells like BCSCs as it is capable of detecting one epithelial cell in up to 107 peripheral blood mononuclear cells (Hu et al., 2010).

In veterinary oncology, M. Michishita and coworkers (Michishita et al., 2013) were the first to use the FCA to recognize TICs in feline mammary carcinoma cell lines. Also, the diagnostic precision of FCA to discriminate neoplastic from non-neoplastic lymphoproliferative anarchies in cats was reported in a study by Martini and colleagues (Martini et al., 2018).

For the first time in cats, we proposed to detect and enumerate cBCSCs in feline peripheral blood using the FC analysis against their specific cellular markers: CD44 / CD24- combination and CD133+ individually. We aimed to evaluate the sensitivity and specificity of this technique for the early diagnosis of FMC using the receiver operating characteristic (ROC) curve and tried to set up a cutoff point of diagnostic value for each used phenotypic marker/ combination.

\section{MATERIALS AND METHODS}

\section{Animals Groups}

This study was carried out in compliance with the ARRIVE guidelines (du Sert, Ahluwalia, et al., 2020; du Sert, Hurst, et al., 2020), and Studies of diagnostic accuracy (STARD) 
guidelines (Bossuyt et al., 2015). All animals under investigation in the study were handled following the Association for Assessment and Accreditation of Laboratory Animal Care and Office of Laboratory Animal Welfare (AAALAC) guidelines under the direction of the Institutional Animal Care and Use Committee at Cairo University (CU-IACUC) that approved the protocol (code: CU II F 9 16) renewed by (Vet CU28/04/2021/266). Written informed consent was provided by the owners of the cats for recruitment in our research.

Between March 2019 and January 2021, 1ml whole blood samples were collected from each 26 client-owned female cats of different breeds that were admitted to the referral animal hospital of the Faculty of Veterinary Medicine at Cairo University.

We collected nine whole blood samples from 9 healthy queens that have been free of any disease (GA: healthy cats). The other 17 EDTA blood samples were collected from 17 female unspayed cats, diagnosed with mammary tumor (GB: diseased cats), as shown in (Table 1). All samples were stored at $4 \mathrm{C}^{\circ}$ till analysis (within max 2-4hrs. post collection) (Diks et al., 2019).

Table 1: Descriptions of animal groups.

\begin{tabular}{llll}
$\begin{array}{l}\text { Group } \\
\text { name }\end{array}$ & Group description & Breeds & Total \\
GA & $\begin{array}{l}\text { Healthy female cats with no } \\
\text { mammary tumors or other }\end{array}$ & $\begin{array}{l}\text { 3 Siamese } \\
\text { pathological conditions }\end{array}$ & $\begin{array}{l}\text { 2 Mongrel } \\
\text { 4 Persian }\end{array}$ \\
& FB & 12 Persian & 17 \\
& $\begin{array}{l}\text { Female cats diagnosed positive } \\
\text { with a mammary tumor } \\
\text { (Note: } 7 \text { cats showed lung }\end{array}$ & 3 Siamese \\
& 2 Mongrel \\
& lesions) & & \\
\hline
\end{tabular}

Then, all the diseased cats were introduced to a new treatment research study which will be published soon.

Diagnosis of mammary tumor in GB animals was performed by through physical examination, radiographic imagining for lung metastasis, and histopathological analysis to tumor biopsies by hematoxylin and eosin ( $\mathrm{H} \& \mathrm{E})$ and confirmed by Immunohistochemistry (IHC).

\section{Physical and Radiographic Examination and} Pathological studies

In the diseased cases (GB), we measured the dimensions of each tumor using calipers, and for detection of lung metastasis, we used the X-ray machine (Fischer, Berlin, Germany). The radiographic setting factors were as previously described (E1-Rasikh et al., 2021). We followed the modified World Health Organization grading system to determine primary tumor size and the presence of lung metastasis
(Cassali et al., 2019).

Tumor biopsies were collected from tumors $>3 \mathrm{~cm}(\mathrm{~T} 1 \&$ T2 categories) while tumors of the T3 category $(>3 \mathrm{~cm})$ (11 tumors in 7 diseased cases) have been surgically removed by our surgeons' team in the Surgery Department, Faculty of Veterinary Medicine, Cairo University as previously mentioned (Farghali et al., 2017; Ali et al., 2019). We used Methadone (Comfortan $-10 \mathrm{mg} / \mathrm{ml}, 0.1 \mathrm{mg}$ / $\mathrm{Kg}-0.3 \mathrm{mg} / \mathrm{Kg}$ b.wt SC/IM; Dechra,UK ) every three to six hours post operative. The peri-operative measures were performed according to AAHA/AAFP pain management guidelines for dogs and cats (Epstein et al., 2015).

The pathological assessment of tumor samples was performed in the Pathology Department at Animal Health Research Institute (AHRI), Dokki, Giza. The formalin-fixed paraffin-embedded sections from tumor biopsies were processed routinely for $\mathrm{H} \& \mathrm{E}$ staining according to Suvarna. et al (S.Kim Suvarna, Christopher Layton, 1989) and Ali et al (Ali et al., 2018).

Further sections on positively charged coated slides were used for IHC (DAP- Peroxidase and Alkaline Phosphatase) technique using antibodies against (CD44 (CD44 Antibody IM7, Bio-Rad Laboratories) and CD133 (Recombinant Anti-CD133 antibody [EPR16508], Abcam, UK). These human antibodies were reported to have cross-reactivity with feline and canine tissues (Barbieri et al., 2012; Park, 2013; Granados-Soler et al., 2018). We used the BLASTP tool (BLASTP 2.12.0') (Altschul et al., 2005) to assess the similarity between Human CD133 (O43490.1) and that of feline due to lake of evidence of cross reactivity antibodies. The query coverage was $96 \%$ with E-value (0.0) [S.1,2].

Proper negative controls were used according to The Histochemical Society's standards (Hewitt et al., 2014). We could not assess the expression of CD24 because of the absence of antibody cross-reaction with the feline antigen. We implemented the IHC technique according to the kit's manufacture instructions.

\section{Flow Cytometer analysis}

We analyzed whole $\mathrm{PB}$ samples to enumerate Circulatory Breast Cancer Stem Cells (cBCSCs) by flow cytometer (Coulter Epics XL, Beckman Coulter, CA) using Flow Jo software (BD) (A1-Salman et al., 2020). cBCSCs were detected against the following specific cell surface markers in each sample: CD133+ (CD133/1 (AC133) Antibody, anti-human, PE, REAlease, Miltenyi Biotec Germany) in a single test and $\mathrm{CD} 44^{+} / \mathrm{CD} 24^{-}$combination in another test (PE Mouse Anti-Human CD44v6 (2F10) BD Biosciences, USA and FITC Mouse Anti-Human CD24 
(ML5), BD Biosciences, USA) according to their manufacture structure. We used CD44v6 antibody as it is nearly absent on most of leukocytes and many studies have approved it as a prognostic marker for BC (Mackay et al., 1994; Liu et al., 2016; Qiao et al., 2018).

The human antibodies used have already been reported to stain feline samples by FCA (Michishita et al., 2013; Pang et al., 2013). One tube served as a negative control (unstained cells) for each sample. Lysis of RBC and fixation of peripheral blood leukocytes after staining with specific antibodies were performed according to the Thermo Fisher Scientific flow cytometry protocol for staining cell surface antigens. Briefly, (1) $10 \mathrm{~mL}$ of diluted eBioscience $^{\mathrm{TM}}$ 10X RBC Lysis Buffer (Multi-species) (Invitrogen, Thermofisher) were added to each PB sample ( $1 \mathrm{ml}$ blood), mixed well and incubated at room temperature for $15 \mathrm{~min}$, followed by centrifugation for $10 \mathrm{~min}$. Then, the cell pellets were resuspended and washed three times by $2 \mathrm{ml}$ of eBioscience $^{\mathrm{TM}}$ Flow Cytometry Staining Buffer (Invitrogen, Thermofisher) and resuspended in $300 \mu \mathrm{l}$ of the same previous buffer. (2) For each $100 \mu$ of the previous suspension, we added $20 \mu \mathrm{L}$ of eBioscience ${ }^{\mathrm{TM}}$ Fc Receptor Binding Inhibitor Polyclonal Ab, incubated for $15 \mathrm{~min}$ at room temperature, washed and resuspended in $300 \mu$ of staining buffer. Then, $20 \mu 1$ from each specific conjugated antibody (either $\mathrm{CD} 133^{+}$separately or $\mathrm{CD} 44^{+} / \mathrm{CD} 24^{-}$combination) were added to each $100 \mu \mathrm{l}$ of the previous suspension, vortexed gently, and incubated for $30 \mathrm{~min}$ at $4 \mathrm{C}^{\circ}$ in the dark. About $2 \mathrm{~mL}$ of diluted eBioscience ${ }^{\mathrm{TM}} 10 \mathrm{X} \mathrm{RBC} \mathrm{Ly}-$ sis Buffer (Multi-species) (Invitrogen, Thermofisher) was added to the previous combination, incubated for $15 \mathrm{~min}$ in the dark, washed twice in the previously used staining buffer, then resuspended in $500 \mu \mathrm{l}$ of this same reagent. (3)10-20 $\mu \mathrm{l}$ of eBioscience ${ }^{\mathrm{TM}}$ 7-AAD Viability Staining was added to the final cell suspension 15 min prior to sample acquisition on the cytometer.

cBCSCs were counted by recording all events in the whole suspension. BCSCs were identified as $\mathrm{CD} 133^{+}$or $\mathrm{CD} 44^{+}$/ $\mathrm{CD} 24^{-}$combination. The results are represented as mean \pm standard deviation (SD), median, and range.

\section{STATISTICAL ANALYSIS}

The data were checked for errors. Normality was checked using descriptive statistics, plots (histogram and box plot), and the Shapiro Wilk test. Comparison of the $\mathrm{CD} 44^{+} / \mathrm{CD} 24^{-}$and $\mathrm{CD}_{133^{+}}$absolute number of cells was implemented using the Mann Whitney $U$ test. We used a binary logistic regression to define the cancer probability using the enumerated cellular markers. Area Under the Curve, sensitivity, specificity, and likelihood ratios, and cutoff points were calculated. Sensitivity values were plotted against complementary specificity values in the receiver operating characteristic (ROC) curve. The significance level was set at a $p$-value of 0.05 (Younus et al., 2019). For data analysis, we used MedCalc Statistical Software version 19.2.6 (MedCalc Software Ltd, Ostend, Belgium; https://www.medcalc.org;2020).

\section{RESULTS}

\section{Physical and Radiographic EXamination}

Physical examination of GB revealed about 39 tumors of different size categories and sites (Fig.1; A-C). Data considering the incidence of cats' tumor numbers, sites, and sizes are shown in (Table 2). The radiographic examination diagnosed seven cats with lung metastasis (41.18\%) among the diseased groups (Fig.1; D).

Table 2: Tumor characteristics of the diseased cases (GB).

\begin{tabular}{|c|c|c|}
\hline & & GB (n=39 tumors) \\
\hline \multirow{5}{*}{$\begin{array}{l}\text { Tumor site: } \mathrm{n} \\
(\%)\end{array}$} & Caudal abdomen & $11(28.2 \%)$ \\
\hline & Caudal thoracic & $8(20.5 \%)$ \\
\hline & Cranial abdomen & $8(20.5 \%)$ \\
\hline & Cranial thoracic & $6(15.4 \%)$ \\
\hline & Inguinal & $6(15.4 \%)$ \\
\hline \multirow[t]{2}{*}{ Side: $n(\%)$} & Left & $17(43.6 \%)$ \\
\hline & Right & $22(56.4 \%)$ \\
\hline \multirow{3}{*}{$\begin{array}{l}\text { Size category: } \\
\mathrm{n}(\%)\end{array}$} & $\mathrm{T} 1(<2 \mathrm{~cm})$ & $25(64.1 \%)$ \\
\hline & $\mathrm{T} 2(2-3 \mathrm{~cm})$ & $3(7.69 \%)$ \\
\hline & $\mathrm{T} 3(>3 \mathrm{~cm})$ & $11(28.2 \%)$ \\
\hline
\end{tabular}
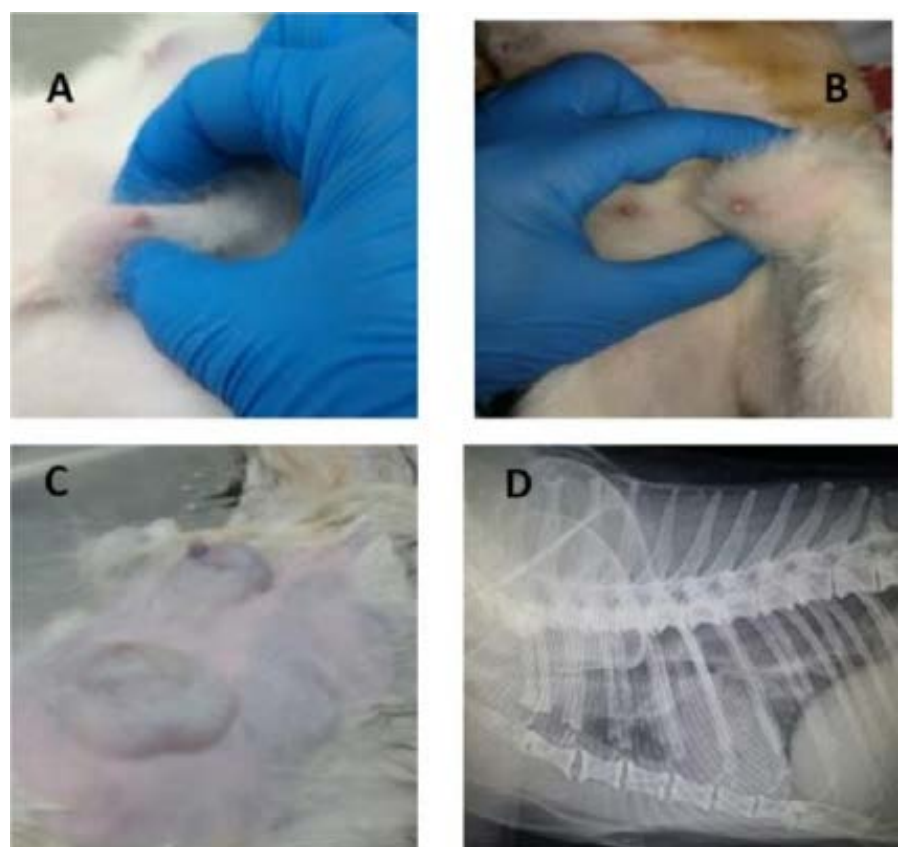

Figure 1: Feline physical and radiographic examination. Physical and radiographic examination of diseased animals (A-D). Queens with different tumor sizes (A-C), and Queen with lung metastasis (D). 
Table 3: Statistical analysis of the (CD44 $\left.{ }^{+} \mathrm{CD} 24^{-}\right)$and $\mathrm{CD} 133^{+}$Cells enumeration in the diseased and controls (GA $\& G B)$.

\begin{tabular}{|c|c|c|c|c|}
\hline & & $\begin{array}{l}\text { Diseased } \\
(\mathrm{n}=17)\end{array}$ & $\begin{array}{l}\text { Controls } \\
(n=9)\end{array}$ & $P$-value \\
\hline \multirow[t]{2}{*}{$\mathrm{CD} 44^{+} / \mathrm{CD} 24^{-}$cells } & Mean (SD) & $19003.06(18714.61)$ & $1169.89(90.67)$ & \multirow[t]{2}{*}{$<0.0001^{*}$} \\
\hline & Median (Min - Max) & $15765(26-62043)$ & $161.00(38-276)$ & \\
\hline \multirow[t]{2}{*}{$\mathrm{CD}_{133^{+}}$cells } & Mean (SD) & $298.82(640.205)$ & $5.00(4.74)$ & \multirow[t]{2}{*}{$<0.0001^{\prime}$} \\
\hline & Median (Min - Max) & $45.00(13-2544)$ & $4.00(0-14)$ & \\
\hline
\end{tabular}

*Statistically significant at $p$-value $\leq 0.05$.

Table 4: Incidence of lung metastasis, Mean \pm standard deviation $(\mathrm{SD})$, median and range of $\left(\mathrm{CD}^{4} 4^{+} / \mathrm{CD}^{-} 4^{-}\right)$and CD133+ cells population in GB queens.

$\begin{array}{llll}\text { Avarage } & & \text { Lung Mets. n (\%) } & \\ & & \text { Yes } & \text { No } \\ & & 7(41.18 \%) & 10(58.82 \%) \\ \left(\mathrm{CD} 44^{+} / \mathrm{CD} 24^{-}\right) & \text {Mean (SD) } & 24210.86(15037.42) & 15357.60(20881.40) \\ \text { cells } & \text { Median (Min-Max) } & 21323(5295-45784) & 4047(26-62043) \\ & \text { P value } & 0.143 & \\ \text { CD133+ } & \text { Mean (SD) } & 176.71(400.992) & 384.30(775.715) \\ \text { cells } & \text { Median (Min-Max) } & 28(14-1086) & 89(13-2544) \\ & \text { P value } & 0.064 & \end{array}$

Table 5: Area Under the Curve for (CD44+/CD24-) and CD133+ cells "Diagnostic ability".

\begin{tabular}{|c|c|c|c|}
\hline & & CD44+/CD24- & CD133 \\
\hline \multirow[t]{3}{*}{ AUC } & Estimate & 0.902 & 0.990 \\
\hline & $95 \% \mathrm{CI}$ & $(0.721-0.983)$ & $(0.850-1.00)$ \\
\hline & $P$-value & $<0.0001^{*}$ & $<0.0001^{*}$ \\
\hline \multirow[t]{2}{*}{ Sensitivity } & Estimate & 88.24 & 100 \\
\hline & $95 \% \mathrm{CI}$ & $63.6-98.5$ & $80.5-100$ \\
\hline \multirow[t]{2}{*}{ Specificity } & Estimate & 100 & 88.89 \\
\hline & $95 \% \mathrm{CI}$ & $66.4-100$ & $51.8-99.7$ \\
\hline \multirow[t]{2}{*}{$\mathrm{LR}+$} & Estimate & $-* *$ & 9 \\
\hline & $95 \% \mathrm{CI}$ & $-* *$ & $1.4-57.1$ \\
\hline \multirow[t]{2}{*}{ LR- } & Estimate & 0.12 & 0 \\
\hline & $95 \% \mathrm{CI}$ & $0.03-0.4$ & - \\
\hline Youden index & Estimate & 0.88 & 0.89 \\
\hline Cutoff point & Estimate & $>276$ & $>12$ \\
\hline
\end{tabular}

AUC: Area Under Curve, CI: Confidence Interval LR': positive likelihood ratio, LR': negative likelihood ratio. *Statistically significant at $\mathrm{p}$-value $\leq 0.05$. ${ }^{*}$ Absence of positive $\mathrm{LR}$ is due to $100 \%$ specificity.

\section{Pathological studies}

All the examined tumor biopsies revealed features of mammary gland carcinoma (either ductal, tubular, or adenocarcinoma) when stained with H\&E (Fig.2; A-C). In IHC, CD44 and CD133 demonstrated positive peroxidase reaction in all examined tissues either in the cell membrane of the lining epithelium (CD44) alone or with cytoplasm (CD133) (Fig.2; D\&E).

December 2021 | Volume 9 | Issue 12 | Page 2205

\section{FLOWCYTOMETRY EVALUATION}

The cells with the phenotypic expression of (CD44 $/$ CD24-) combination and $\mathrm{CD} 133^{+}$that correspond with breast cancer stem cells were detected and enumerated in each PB sample in this study (GA and GB) by using a flow cytometer (Fig.3). The count of (CD44+CD24) cells and $\mathrm{CD}_{133^{+}}$populations were significantly prevalent in cats diagnosed with mammary tumor $(\mathrm{GB} ; \mathrm{n}=17)$ vs apparently healthy cats $(\mathrm{GA} ; \mathrm{n}=9)(p<0.0001)$. Mean \pm standard 

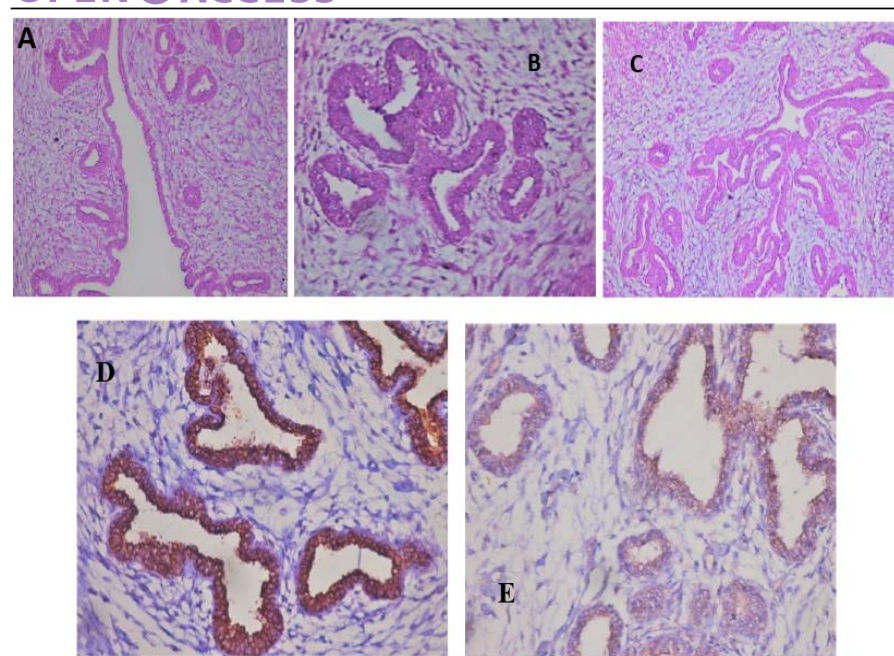

Figure 2: Feline mammary carcinoma. Representative pictures for $\mathrm{H} \& \mathrm{E}$ demonstrated hyperplasia of ductal epithelial with gland formation (A-C) (H\&E: A, C X 200 \& B X 400). Positive CD44 peroxidase reaction (brown color) in the cell membrane of lining epithelium (D) (CD44-peroxidase X 400). IHC showed a positive CD133 peroxidase reaction (brown color) in both cytoplasm and cell membrane of ductal lining epithelium (E) (CD133peroxidase X 200).
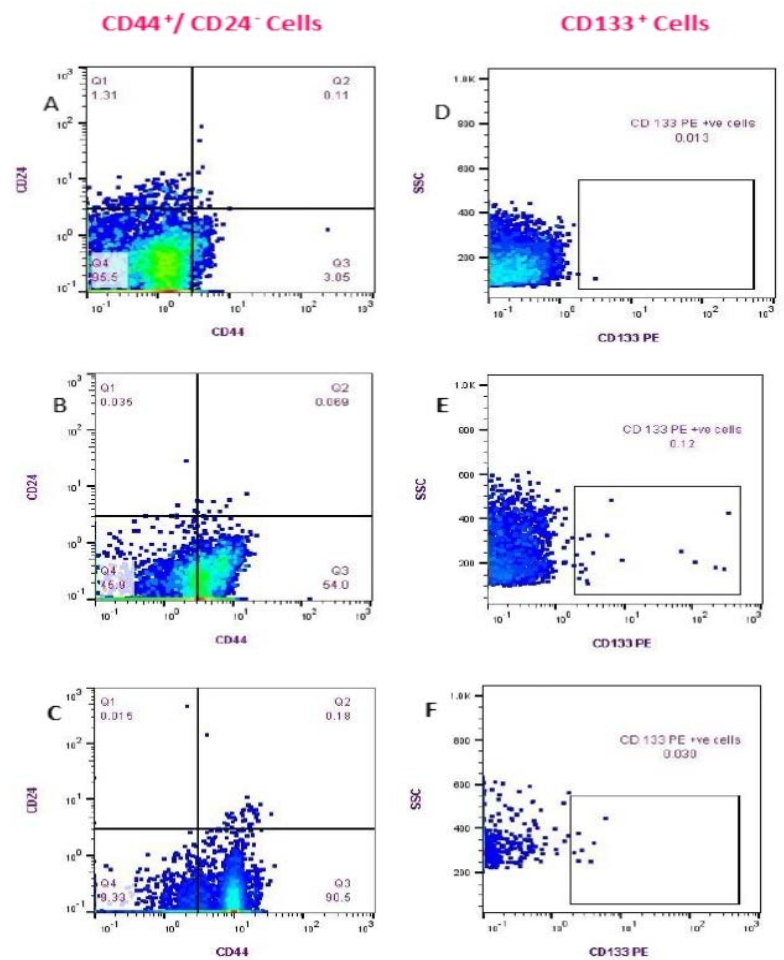

Figure 3: Flow cytometry detection of (CD44+/CD24- ) and CD133+ cell populations in Feline PB. (Fluorescence level of CD44 (PE) versus CD24 (FITC) (A-C)); Healthy cat (A), a diseased cat without lung metastasis (B) and diseased cat with lung metastasis (C). The data are representative of one cat in each animal group (GA, GB). Fluorescence level of CD133 (PE) versus cellular complexity (SS: SS) (D-F); Healthy cat (D), Diseased cat without lung metastasis (E), and diseased cat with lung metastasis $(\mathrm{F})$.

deviation (SD), median, and range of $\mathrm{CD}^{-} 4^{+} / \mathrm{CD} 24^{-}$cells and $\mathrm{CD} 133^{+}$phenotypes of control and diseased groups are shown in (Table 3). Queens that diagnosed with lung metastasis (n:7) showed remarkable increase in the (CD44 / CD24-) cell populations over the rest of the GB (n:10). On the contrary, the $\mathrm{CD} 133^{+}$cells count was relatively higher in female cats without metastasis than those showed lung metastasis (Table 4).

\section{Evaluation of Diagnostic POTENCY OF $\left(\mathrm{CD} 44^{+}\right.$} CD24-) AND CD133+ CELLS ENUMERATION IN FELINE MAMMARY TUMORS

The receiver operating characteristic (ROC) analysis ( $\mathrm{Ta}-$ ble 5) revealed an excellent AUC value for both (CD44+ $\mathrm{CD} 24^{-}$) and CD133+ phenotypes (excellent Ref. ratio between 0.9 and 1) with $100 \%$ sensitivity of CD133+ cells and $88.24 \%$ of $\left(\mathrm{CD} 44^{+/} \mathrm{CD} 24^{-}\right)$cells (Fig. 4). The optimal cutoff points of ( $>276)$ for $\left(\mathrm{CD} 44^{+/} \mathrm{CD} 24^{-}\right)$cells and $(>12)$ for $\mathrm{CD} 133^{+}$cells generate the high Youden index of 0.88 and 0.89 , respectively (Table 5 ).

A

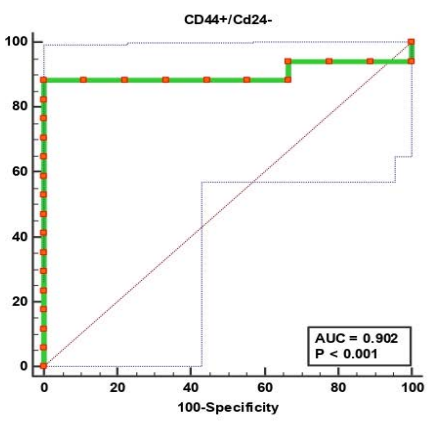

B

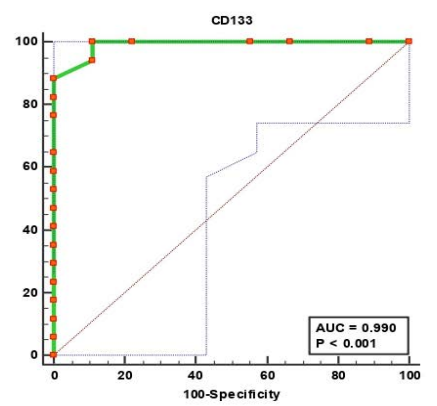

Figure 4: Receiver operating characteristic (ROC) curves. (CD44+/CD24-) cells (A) and CD133+ cells (B).

Table 6: Binary logistic regression.

$\begin{array}{llll} & \text { OR } & \mathbf{9 5 \%} \text { CI } & \boldsymbol{P} \text {-value } \\ \left(\mathrm{CD} 44^{+} / \mathrm{CD} 24\right) \text { cells } & 1.004 & (0.997-1.010) & 0.297 \\ \mathrm{CD}^{2} 33^{+} \text {cells } & 2.240 & (0.251-19.956) & 0.470\end{array}$

Dependent variable: Ref category is having cancer. OR: odds ratio. CI: Confidence Interval. 
The Odds Ratios (OR) (Table 6) of the binary logistic regression analysis evaluated the correlation between cancer occurrence and cBCSCs counts with (1.004) OR for $\left(\mathrm{CD} 44^{+/} \mathrm{CD} 24^{-}\right)$population and (2.240) OR for CD133 ${ }^{+}$ cells. However, these results are not significant $(P<0.05)$.

\section{DISCUSSION}

CTCs and their subpopulation BCSCs are characteristic of "Active" tumor points (that potentially initiate metastasis) (Lopresti et al., 2019). Consequently, accurate enumeration of $\mathrm{BCSC}$ with FCA depending on their specific cellular markers (CD44+/CD24) and /or CD133+) is important.

Herein, we document the first time the flow cytometry quantitative analysis of $\mathrm{BCSC}$ s in the $\mathrm{PB}$ of cats diagnosed with the mammary tumor. The results showed that BCSCs could be detected and counted in the PB of feline depending on their definite cellular markers ((CD44 $4^{+}$ CD24-) and $\mathrm{CD} 133^{+}$); FCA is a sensitive, specific, and rapid diagnostic tool for mammary carcinoma and we also established a cutoff value of diagnostic significance for both $\left(\mathrm{CD} 44^{+} / \mathrm{CD} 24^{-}\right)$and $\mathrm{CD} 133^{+}$populations.

To overcome the paucity of BCSCs, we imitated the flow cytometry analysis technique previously reported (Al-Hajj et al., 2003; Martini et al., 2020). This strategy included all events in the whole suspension, verified by a back-gating method based on cellular morphologic properties (forward scatter-height [FSC-H] vs. side scatter-height [SSC-H]), excluding dead cells, and with the proper acquisition, we adjusted the speed according to the number of events to enhance detection sensitivity [S.3].

In the current prototype, (CD44 $\left./ \mathrm{CD} 24^{-}\right)$and $\mathrm{CD} 133^{+}$ cell populations were detected in $\mathrm{PB}$ of all animals under investigation with a statistically significant difference between diseased group $(n=17)$ and healthy queens $(n=9)$ $(p<0.0001)$.

These flow cytometry outcomes were utterly matched with our results of the initial clinical and IHC diagnosis. The same diseased positive groups gave statistically significant higher values in the flow cytometry analysis. Our findings are similar in humans as many studies validate the BCSC expression as a diagnostic and prognostic marker for aggressive breast cancers (Matsuoka and Yashiro, 2015; Sayed et al., 2016; Mansoori et al., 2017; Lee et al., 2019; Elbaiomy et al., 2020).

Previous studies have proposed flow cytometry as the best laboratory tool for detecting rare cell populations like BCSCs in blood as it can identify cells at frequencies as low as $0.0001 \%$ (Goodale et al., 2009; Watanabe et al., 2014). Our ROC curve analysis strongly supported this conclusion by a sensitivity of $88.24 \%$ for $\left(\mathrm{CD} 44^{+} / \mathrm{CD} 24^{-}\right)$ cell population and $100 \%$ for $\mathrm{CD}_{133^{+}}$cell population. While specificity was $100 \%$ and $88.89 \%$, respectively. Furthermore, the ROC curve gave an excellent AUC value of 0.902 (95\% CI: $0.721-0.983)$ and 0.990 (95\% CI: 0.850 - 1.00) for $\left(\mathrm{CD} 44^{+} / \mathrm{CD} 24^{-}\right)$and $\mathrm{CD} 133^{+}$expressions, respectively (Table 5). These presented findings confirm the former conclusion about the diagnostic accuracy of FCA to distinguish tumorigenic from non-tumorigenic lymphoproliferative disorders in cats (Martini et al., 2018).

For the first time in cats, we set up a diagnostic significant cutoff value for the measurements of cBCSCs in $1 \mathrm{~mL}$ of feline peripheral blood, which is $>276$ for $\left(\mathrm{CD} 44^{+} / \mathrm{CD} 24^{-}\right)$ cells and $>12$ for $\mathrm{CD} 133^{+}$cells that generated a Youden index of 0.88 and 0.89 , respectively. In humans, no estimated diagnostic cut-off value for $\mathrm{CBCSC}$ s was established yet. However, prognostic cutoff points of $2 \mathrm{CTC} / 4 \mathrm{ml}$ blood in one study and $3 \mathrm{CTC} / 1 \mathrm{ml}$ blood in another have been reported (Lopresti et al., 2019; Jin et al., 2020).

The same is also noticed among canine investigations; there is no clear estimated diagnostic cutoff point for cBCSCs. However, a value of zero CTCs in the healthy negative control dogs was reported in a study by L. Marconato. et al (Marconato et al., 2019).

The stress of handling and speed during the venipuncture and the procedure site might affect hematology results by shifting up the RBC and elevating the WBC count, which might explain the relatively high values of the established cutoff points in the feline. So, it is recommended to restrict sampling to one person with standardized procedures (O'Brien et al., 1998). Upon this conclusion, we cannot exclude such an effect on CTCs and their subpopulation (cBCSCs). Also, on luminal epithelial cells of the feline malignant mammary tumor, the upregulation of $\mathrm{P}-\mathrm{Cadherin}$ and loss of expression or abnormal function of E-cadherin increase tumor cell proliferation, motility, invasiveness, high infiltrative growth, and the presence of neoplastic emboli that consequently increase CTCs and $\mathrm{cCSCs}$ populations in queens with mammary tumor (Figueira et al., 2014).

We also applied Binary Logistic Regression analysis for the first time in queens to assess the strength of association between $\mathrm{CD} 44^{+} / \mathrm{CD} 24^{-}$or $\mathrm{CD} 133^{+}$counts and having breast cancer as independent factors. The odds of having a mammary tumor were 1.004 times as likely to have one CD44+CD24 cell and 2.240 times as likely to have one $\mathrm{CD} 133^{+}$cell. Previous studies have measured the strength of the association between BCSCs and disease prognosis 
in humans (Elbaiomy et al., 2020), and canines (Marconato et al., 2019). Nevertheless, this association between cBCSCs and having mammary tumors is not statistically significant $(P<0.05)$ (Table 6), which may be related to the relatively low number of animals used in this study.

Previous studies have proposed the role of Epithelial-Mesenchymal Transition (EMT) during the starting of the metastasis process (Yang et al., 2015). EMT enables carcinoma cells to gain migratory and invasive abilities together with obtaining stemness characteristics. This transition helps tumor cells escape from the primary tumor lesions, intravasate into the circulation, and disseminate at distant secondary tumor sites (Mani et al., 2008; Yilmaz and Christofori, 2009). Tumor epithelial cells that undergo EMT show upregulation of CD44 down-regulation of CD24 and other stem cell markers (Mani et al., 2008). These events could explain the remarkable increase of $\left(\mathrm{CD} 44^{+} / \mathrm{CD} 24\right)$ cell population in the diseased cats with lung metastasis more than the rest of the diseased group. Thus, our results came compatible with previous studies which confirmed that the (CD44 $\left./ \mathrm{CD} 24^{- \text {/low }}\right)$ cell population is associated with boosted invasion and metastasis (Baba and Câtoi, 2007), and so we are suggesting that $\left(\mathrm{CD} 44^{+} / \mathrm{CD} 24^{-/ \text {low }}\right)$ cell enumeration could be used as a prognostic tool for metastasis initiation and treatment monitoring in the feline.

Several former articles demonstrated the ability of neoplastic cells to adapt to the state of low oxygen accessibility (hypoxia). Almost half of breast cancer lesions, enfold many hypoxic regions varying in amount and size (Bhandari et al., 2019). These hypoxic regions are reported to be associated with clinically aggressive tumor behavior (Walsh et al., 2014). The expression of CD133 was informed to be induced by low oxygen availability. Therefore, an increase in CD133expression can be considered an aggressive tumor evolution marker with prognostic and predictive values (Brugnoli et al., 2019), and might explain why, in our investigation, the CD133+ cells count was relatively higher in female cats without metastasis than those with metastasis.

\section{CONCLUSION}

In conclusion, during this study, we assessed the diagnostic significance of the flow cytometer enumeration of cBCSCs for the first time in the feline PB. The (ROC) analysis revealed excellent AUC rates (0.902 and 0.990) for both $\left(\mathrm{CD} 44^{+/} \mathrm{CD} 24^{-}\right)$and $\mathrm{CD} 133^{+}$phenotypes respectively. Also, we established a cutoff point of diagnostic values for both $\left(\mathrm{CD} 44^{+} / \mathrm{CD} 24^{- \text {low }}\right)$ and $\mathrm{CD} 133^{+}$cell populations ( $>276$ and $>12$ ), respectively. In addition, our team used the Odds Ratio to measure the strength of the asso- ciation between $\left(\mathrm{CD} 44^{+} / \mathrm{CD} 24^{- \text {low }}\right)$ and $\mathrm{CD} 133^{+}$cells detection and mammary tumor occurrence that was (1.004) OR for $\left(\mathrm{CD}_{4} 4^{+} \mathrm{CD} 24^{-}\right)$population and (2.240) OR for CD133+ cells.

Since our investigation was based on a relatively low number of subjects, we recommend applying the mentioned FCA diagnostic technique to a large-scale animal population and investigating any correlation between tumor size, sites, numbers, and circulatory BCSCs count. However, we noticed a nonsignificant correlation between lung metastasis and upregulation of $\left(\mathrm{CD} 44^{+} / \mathrm{CD} 24^{- \text {low }}\right)$ cells in queen's circulation, further separate studies about the relation of $\mathrm{FC}$ enumeration of the $\mathrm{cBCSC}$ and feline mammary tumor metastasis are recommended.

In addition, we endorse including cases with benign mammary conditions such as benign tumors or hyperplasia to evaluate the ability of FCA to discriminate between benign and malignant diseases. We also suggest running a comparative analysis between the number of $\mathrm{cCSC}$ and their number in the solid tumor besides applying the previous diagnostic regime as a model in human breast oncology studies.

One of this study's limitations; is that we can't run a single flow panel with both $\mathrm{CD} 44^{+}, \mathrm{CD} 24^{-}$, and $\mathrm{CD} 133^{+}$as the available CD44 and the CD133 antibodies were of the same fluorophore (PE).

\section{ACKNOWLEDGMENTS}

We thank Prof. Dr. Naglaa M. Alkalamawy (Pathology Department at Animal Health Research Institute (AHRI), Egypt) for examination and imaging the pathological slides. We thank Assistant lecturer; Hams Abdelrahman (Dental Public Health Department at Alexandria University, Egypt) for performance of all statistical analysis. We thank Christopher P Cook and Aymen Khalifa (Department of Dermatology, University of California, San Francisco, San Francisco CA, USA) for their generous contribution in editing of flow cytometry analysis.

\section{CONFLICT OF INTEREST}

No potential competing of interest was reported by authors.

\section{AUTHORS CONTRIBUTION}

Data curation, Rasha Elsabagh and Ibrahim Emam; Funding acquisition, Rasha Elsabagh and Haitham Fargali; Investigation, Rasha Elsabagh and Ibrahim Emam; Methodology, Haitham Fargali; Resources, Rasha Elsa- 
bagh, Haitham Fargali and Ibrahim Emam; Supervision, Haitham Fargali, Eman Ragab and Abdelfattah Nada; Validation, Rasha Elsabagh and Haitham Fargali; Visualization, Rasha Elsabagh; Writing - original draft, Rasha Elsabagh; Writing - review \& editing, Haitham Fargali. Salah A. Selim: Conceptualization, Methodology, Writing - Review \& Editing, Supervision, Project administration.

\section{REFERENCES}

-Akbarzadeh M, Maroufi NF, Tazehkand AP, et al. (2019). Current approaches in identification and isolation of cancer stem cells. J. Cell Physiol. 234(9):14759-14772. https:/doi. org/10.1002/jcp.28271

-Al-Hajj M, Wicha MS, Benito-Hernandez A, Morrison SJ, Clarke MF (2003). Prospective identification of tumorigenic breast cancer cells. Proc. Natl.Acad. Sci.U S A. 100(7):39833988. https:/doi.org/10.1073/pnas.0530291100

-Ali IH et al (2018). 'Pathological and Immunological Study On Infection With Escherichia Coli In ale BALB/c mice', J. Phys. Conference Series. 1003(1), p. 012009. https:/doi.org/ 10.1088/1742-6596/1003/1/012009.

-Ali MRK et al. (2016). 'Treatment of natural mammary gland tumors in canines and felines using gold nanorods-assisted plasmonic photothermal therapy to induce tumor apoptosis', Int. J. Nanomed. 11: 4849-4863. https:/doi.org/ 10.2147/ IJN.S109470.

-Ali MRK, Farghali HAM, Wu Y, et al (2019). Gold nanorodassisted photothermal therapy decreases bleeding during breast cancer surgery in dogs and cats. Cancers (Basel). 11(6):851. https:/doi.org/10.3390/cancers11060851

-Al-Salman HNK et al. (2020). '2-Benzhydrylsulfinyl-Nhydroxyacetamide-Na extracted from fig as a novel cytotoxic and apoptosis inducer in SKOV-3 and AMJ-13 cell lines via P53 and caspase- 8 pathway', Euro. Food Res. Technol. 246:8, 246(8): 1591-1608. https:/doi.org/ 10.1007/S00217020-03515-X.

-Altschul, S. F. et al. (2005) 'Protein database searches using compositionally adjusted substitution matrices', The FEBS Journal, 272(20), pp. 5101-5109. https:/doi.org/ 10.1111/J.1742-4658.2005.04945.X.

- Baba A, Câtoi C (2007). Capítulo 11, MAMMARY GLAND TUMORS. In: Comparat. Oncol. ; 2007. https://www.ncbi. nlm.nih.gov/books/NBK9542/

- Barbieri F, Thellung S, Ratto A, et al (2015). In vitro and in vivo antiproliferative activity of metformin on stem-like cells isolated from spontaneous canine mammary carcinomas: Translational implications for human tumors. BMC Cancer. 15(1). https:/doi.org/10.1186/s12885-015-1235-8

- Barbieri F, Wurth R, Ratto A, et al (2012). Isolation of stemlike cells from spontaneous feline mammary carcinomas: Phenotypic characterization and tumorigenic potential. Exp. Cell Res. 318(7):847-860. https:/doi.org/10.1016/j. yexcr.2012.02.008

- Bhandari V, Hoey C, Liu LY, et al (2019). Molecular landmarks of tumor hypoxia across cancer types. Nat. Genet.51(2):308318. https:/doi.org/10.1038/s41588-018-0318-2

- Bossuyt PM, Reitsma JB, Bruns DE, et al. (2015). STARD : An updated list of essential items for reporting diagnostic accuracy studies. Clin Chem. 2015;61(12):1446-1452.https:/ doi.org/10.1373/clinchem.2015.246280
-Brugnoli F, Grassilli S, Al-Qassab Y, Capitani S, Bertagnolo V (2019). CD133 in Breast Cancer Cells: More than a Stem Cell Marker.J. Oncol.https:/doi.org/10.1155/2019/7512632.

- Cannon CM (2015). Cats, cancer and comparative oncology. Vet. Sci. 2015;2(3):111-126. https:/doi.org/10.3390/ vetsci2030111

- Cassali GD, Jark PC, Gamba C, et al (2019). Consensus Regarding the Diagnosis, Prognosis and Treatment of Canine and Feline Mammary Tumors-2019. Braz J. Vet. Pathol. 2020(3):555-574. https:/doi.org/10.24070/ bjvp.1983-0246.v13i3p555-574

-De Las Mulas JM, Reymundo C (2000). Animal models of human breast carcinoma: Canine and feline neoplasms. Clin. Transl. Oncol. 2(6):274-281. https:/doi.org/10.1007/ BF02979590

-Diks, A. M. et al. (2019). 'Impact of blood storage and sample handling on quality of high dimensional flow cytometric data in multicenter clinical research', J. Immunolog. Methods. 475(June), pp. 0-1. https:/doi.org/10.1016/j. jim.2019.06.007.

-Du Sert NP, Ahluwalia A, Alam S, et al (2020). Reporting animal research: Explanation and elaboration for the arrive guidelines 2.0. PLoS Biol. 18(7):e3000411. https:/doi. org/10.1371/journal.pbio.3000411

-Du Sert NP, Hurst V, Ahluwalia A, et al (2020). The arrive guidelines 2.0: Updated guidelines for reporting animal research. PLoS Biol. 18(7):e3000410. https:/doi. org/10.1371/journal.pbio.3000410

-Duffy MJ, McDermott EW, Crown J (2018). Bloodbased biomarkers in breast cancer: From proteins to circulating tumor cells to circulating tumor DNA. Tumor Biol. 40(5):101042831877616. https:/doi. org/10.1177/1010428318776169

-Elbaiomy MA, Akl T, Atwan N, Elsayed AA, Elzaafarany M, Shamaa S (2020). Clinical Impact of Breast Cancer Stem Cells in Metastatic Breast Cancer Patients. J. Oncol. https:/ doi.org/10.1155/2020/2561726

-El-Rasikh AM, Farghali HAM, Abdelrahman HA et al (2021). The implication of autoantibodies in early diagnosis and monitoring of plasmonic photothermal therapy in the treatment of feline mammary carcinoma. Sci. Rep. 11: 10441. https://doi.org/10.1038/s41598-021-89894-x

-Epstein, M. et al. (2015) AAHA/AAFP pain management guidelines for dogs and cats. J. American Anim. Hosp. Assoc. 51(2): 67-84. https:/doi.org/ 10.5326/JAAHA-MS-7331

- Farghali HA, AbdElKader NA, Khattab MS, AbuBakr HO (2017). Evaluation of subcutaneous infiltration of autologous platelet-rich plasma on skin-wound healing in dogs. Biosci. Rep. 37(2):20160503. https:/doi.org/10.1042/ BSR20160503

- Figueira AC, Gomes C, de Oliveira JT, et al (2014). Aberrant $\mathrm{P}$-cadherin expression is associated to aggressive feline mammary carcinomas. BMC Vet. Res. 10(1):270. https:/ doi.org/10.1186/s12917-014-0270-z

- Freeman J, Gray ES, Ziman M (2015). 'Circulating tumor cells as biomarkers in cancer', in Biomarkers in Disease: Methods, Discoveries and Applications: Biomarkers in Cancer. Springer Netherlands, pp. 31-51. https:/doi. org/10.1007/978-94-007-7681-4_21.

- Goodale D, Phay C, Postenka CO, Keeney M, Allan AL (2009). Characterization of tumor cell dissemination patterns in preclinical models of cancer metastasis using flow cytometry and laser scanning cytometry. Cytom Part A. 75A(4):344- 
355. https:/doi.org/10.1002/cyto.a.20657

- Granados-Soler JL, Junginger J, Hewicker-Trautwein M, et al (2018). TiHo- 0906: a new feline mammary cancer cell line with molecular, morphological, transition. Sci Rep. 8(1):117. https:/doi.org/10.1038/s41598-018-31682-1

- Hewitt SM, Baskin DG, Frevert CW, Stahl WL, RosaMolinar E (2014). Controls for Immunohistochemistry: The Histochemical Society's Standards of Practice for Validation of Immunohistochemical Assays. J. Histochem. Cytochem. 2014;62(10):693-697. https:/doi. org/10.1369/0022155414545224

-Hu Y, Fan L, Zheng J, et al (2010). Detection of circulating tumor cells in breast cancer patients utilizing multiparameter flow cytometry and assessment of the prognosis of patients in different CTCs levels. Cytom Part A. 2010;77(3):213-219. https:/doi.org/10.1002/cyto.a.20838

-Jabir, MS et al. (2021) 'Green Synthesis of Silver Nanoparticles Using Annona muricata Extract as an Inducer of Apoptosis in Cancer Cells and Inhibitor for NLRP3 Inflammasome via Enhanced Autophagy', Nanomaterials. 11(2): 384. https:/doi.org/10.3390/NANO11020384.

- Jaggupilli A, Elkord E (2012). Significance of CD44 and CD24 as cancer stem cell markers: An enduring ambiguity. Clin. Dev. Immunol. https:/doi.org/10.1155/2012/708036

• Jawad M, Öztürk K, Jabir MS (2021). 'TNF- $\alpha$ loaded on gold nanoparticles as promising drug delivery system against proliferation of breast cancer cells', Materials Today: Proceedings. 42: 3057-3061. https:/doi.org/10.1016/J. MATPR.2020.12.836.

-Jin L, Zhao W, Zhang J, et al (2020). Evaluation of the diagnostic value of circulating tumor cells with CytoSorter ${ }^{\circledR}$ CTC capture system in patients with breast cancer. Cancer Med.9(5):1638-1647. https:/doi.org/10.1002/cam4.2825

- Karabolovski, N. et al. (2015). 'Feline mammary tumors, prevalence, and patho-histological classification', Horizonts, 2:41-49.https:/doi.org/10.20544/HORIZONS.B.03.1.16. P07

-Kaszak I, Ruszczak A, Kanafa S, Kacprzak K, Król M, Jurka P (2018). Current biomarkers of canine mammary tumors. Acta Vet. Scand. 60(1):66. https:/doi.org/10.1186/s13028018-0417-1

- Kazarian A, Blyuss O, Metodieva G, et al (2017). Testing breast cancer serum biomarkers for early detection and prognosis in pre-diagnosis samples. Br J. Cancer. 116(4):501-508. https:/doi.org/10.1038/bjc.2016.433

- Khoo BL, Kumar P, Lim CT, Thiery JP. Genesis of Circulating Tumor Cells Through Epithelial-Mesenchymal Transition as a Mechanism for Distant Dissemination. In: Springer, New York, NY; 2016:139-182. https:/doi.org/10.1007/9781-4939-3363-1_8

-Labelle M, Begum S, Hynes RO (2011) 'Direct Signaling between Platelets and Cancer Cells Induces an EpithelialMesenchymal-Like Transition and Promotes Metastasis', Cancer Cell. 20(5): 576-590. https:/doi.org/10.1016/j. ccr.2011.09.009.

-Lee CH, Hsieh JCH, Wu TMH, et al (2019). Baseline circulating stem-like cells predict survival in patients with metastatic breast Cancer. BMC Cancer. 19(1):1167. https:/ doi.org/10.1186/s12885-019-6370-1

- Liu, F. et al. (2016) 'Biomarkers for EMT and MET in breast cancer: An update (review)', Oncology Letters. Spandidos Publications, pp. 4869-4876. https:/doi.org/10.3892/ ol.2016.5369.
- Liu S, Cong Y, Wang D, et al (2014). Breast cancer stem cells transition between epithelial and mesenchymal states reflective of their normal counterparts. Stem Cell Reports. 2(1):78-91. https:/doi.org/10.1016/j.stemcr.2013.11.009

-Lopresti A, Malergue F, Bertucci F, et al (2019). Sensitive and easy screening for circulating tumor cells by flow cytometry. JCI Insight. 4(14). https:/doi.org/10.1172/jci. insight. 128180

- Mackay, C. R. et al. (1994). 'Expression and modulation of CD44 variant isoforms in humans', J. Cell Biol. 124(1): 71. https:/doi.org/ 10.1083/JCB.124.1.71.

- Mani SA, Guo W, Liao MJ, et al (2008). The EpithelialMesenchymal Transition Generates Cells with Properties of Stem Cells. Cell. ;133(4):704-715. https:/doi.org/10.1016/j. cell.2008.03.027

- Mansoori M, Madjd Z, Janani L, Rasti A (2017). Circulating cancer stem cell markers in breast carcinomas: A systematic review protocol. Syst. Rev. 6(1):262. https:/doi.org/10.1186/ s13643-017-0660-y

- Marconato L, Facchinetti A, Zanardello C, et al (2019). Detection and Prognostic Relevance of Circulating and Disseminated Tumour Cell in Dogs with Metastatic Mammary Carcinoma: A Pilot Study. Cancers (Basel). 11(2):163. https:/doi.org/10.3390/cancers11020163

-Martini, V. et al. (2018). 'Flow cytometry for feline lymphoma: a retrospective study regarding pre-analytical factors possibly affecting the quality of samples', J. Feline Med. Surg. 20(6): 494-501. https:/doi.org/ 10.1177/1098612X17717175.

-Martini V, Bernardi S, Giordano A, Comazzi S (2020). Flow cytometry expression pattern of CD44 and CD18 markers on feline leukocytes. J. Vet. Diagnost. Investig. 32(5):706709. https:/doi.org/10.1177/1040638720945670

- Matsuoka T, Yashiro M (2015). CD133 as biomarker in breast cancer. In: Biomarkers in Disease: Methods, Discoveries and Applications: Biomarkers in Cancer. Springer Netherlands; 429-445. https:/doi.org/10.1007/978-94-007-7681-4_24

-Michishita M, Otsuka A, Nakahira R, et al (2013). Flow cytometric analysis for detection of tumor-initiating cells in feline mammary carcinoma cell lines. Vet. Immunol. Immunopathol. 156:73-81. https:/doi.org/10.1016/j. vetimm.2013.08.006

- Nicolini A, Ferrari P, Duffy M0J (2018). Prognostic and predictive biomarkers in breast cancer: Past, present and future. Semin Cancer Biol. 2018;52:56-73. https:/doi. org/10.1016/j.semcancer.2017.08.010

- O’Brien M, Murphy MG, Lowe JA (1998). Hematology and clinical chemistry parameters in the cat (Felis domesticus). In: J. Nutri. Vol 128. American Institute of Nutrition; 1998:2678S-2679S. https:/doi.org/10.1093/ jn/128.12.2678s

- Pang LY, Blacking TM, Else RW, et al . Feline mammary carcinoma stem cells are tumorigenic, radioresistant, chemoresistant and defective in activation of the ATM/p53 DNA damage pathway. Vet. J. 196(3):414-423. https:/doi. org/10.1016/j.tvj1.2012.10.021

-Park J-HE-SS-YJ-YH-Y (2013). Expression of CD133, CD44, CK7, and OCT4 in Animal Cancers. Korean J. Vet. Res. 53(2):109-115. https:/doi.org/10.14405/ KJVR.2013.53.2.109

- Qiao G-L et al.(2018). 'Prognostic value of CD44v6 expression in breast cancer: a meta-analysis', OncoTargets Therap. 11: 5451-5457. https:/doi.org/ 10.2147/OTT.S156101.

- Sameen AM., Jabir MS, Al-Ani MQ (2020). 'Therapeutic 
combination of gold nanoparticles and LPS as cytotoxic and apoptosis inducer in breast cancer cells', AIP Conference Proceed. 2213. https:/doi.org/ 10.1063/5.0000161.

- Sayed M, Zahran AM, Hassan MSF, Mohamed DO (2016). Circulating Tumor Cells and Cancer Stem Cells: Clinical Implications in Nonmetastatic Breast Cancer. Breast Cancer Basic Clin. Res. 10:BCBCR.S40856. https:/doi. org/10.4137/BCBCR.S40856

-Stephen F. Altschul, John C. Wootton, E. Michael Gertz, Richa Agarwala, Aleksandr Morgulis, Alejandro A. Schäffer,, Yi-Kuo Yu (2005). "Protein database searches using compositionally adjusted substitution matrices", FEBS J. 272:5101-5109.

- Suvarna Kim Layton Christopher BancroftJohn. Bancroft's Theory and Practice of Histological Techniques - 7th Edition. Accessed April 25, 2021. https://www.elsevier. $\mathrm{com} /$ books/bancrofts-theory-and-practice-of-histologicaltechniques/suvarna/978-0-7020-4226-3

-Walsh JC, Lebedev A, Aten E, Madsen K, Marciano L, Kolb HC (2014). The clinical importance of assessing tumor hypoxia: Relationship of tumor hypoxia to prognosis and therapeutic opportunities. Antioxidants Redox Signal. 21(10):1516-1554. https:/doi.org/10.1089/ars.2013.5378

-Watanabe M, Uehara Y, Yamashita N, et al (2014). Multicolor detection of rare tumor cells in blood using a novel flow

S1:

RID: F9K3BM4K01R

Job Title:sp|O43490|

Program: BLASTP

Query: RecName: Full=Prominin-1; AltName: Full=Antigen AC133; AltName: Full=Prominin-like protein 1;

AltName: CD_antigen=CD133; Flags: Precursor ID:

O43490.1(amino acid) Length: 865

Database: RefSeq protein Felis catus Refseq Protein

Sequences producing significant alignments:

Scientific

Common

Description

Name Taxid Score Score cover Value Ident

Len Accession

prominin-1 isoform X3 [Felis catus]

Felis catus domestic cat $9685 \quad 1179 \quad 1179 \quad 96 \%$

$\begin{array}{llll}0.0 & 66.71 & 849 & \text { XP_023109054.1 }\end{array}$

prominin-1 isoform X1 [Felis catus]

Felis catus domestic cat $9685 \quad 1171 \quad 1171 \quad 96 \%$

$\begin{array}{llll}0.0 & 66.23 & 855 & \text { XP_019685284.2 }\end{array}$

prominin-1 isoform X4 [Felis catus]

Felis catus domestic cat $9685 \quad 1159 \quad 1159 \quad 96 \%$

$\begin{array}{llll}0.0 & 65.99 & 840 \quad \text { XP_019685292.2 }\end{array}$

prominin-1 isoform X2 [Felis catus]

Felis catus domestic cat $9685 \quad 1157 \quad 1157 \quad 94 \%$

$\begin{array}{llll}0.0 & 66.75 & 849 & \text { XP_019685287.2 }\end{array}$

Alignments:

>prominin-1 isoform X3 [Felis catus]

Sequence ID: XP_023109054.1 Length: 849 cytometry-based system. Cytom Part A. 85(3):206-213. https:/doi.org/10.1002/cyto.a.22422

-Wu T, Cheng B, Fu L (2017). Clinical applications of Circulating tumor cells in Pharmacotherapy: Challenges and perspectives. Mol. Pharmacol. 92(3):232-239. https:/ doi.org/10.1124/mol.116.108142

-Yang MH, Imrali A, Heeschen C (2015). Circulating cancer stem cells: The importance to select. Chinese J. Cancer Res.. 27(5):437-449. https:/doi.org/10.3978/j.issn.10009604.2015.04.08

-Yilmaz M, Christofori G (2009). EMT, the cytoskeleton, and cancer cell invasion. Cancer Metastasis Rev. 28(1-2):15-33. https:/doi.org/10.1007/s10555-008-9169-0

- Younus A., Al-Ahmer S, Jabir M (2019). 'Evaluation of some immunological markers in children with bacterial meningitis caused by streptococcus pneumoniae', Res. J. Biotechnol. 14(Special Issue I):131-133. Available at: https://www. researchgate.net/publication/332470264_Evaluation of_some_immunological_markers_in_children_with_ bacterial_meningitis_caused_by_Streptococcus_ pneumoniae (Accessed: 1 November 2021).

-Zappulli V, Rasotto R, Caliari D, et al (2015). Prognostic Evaluation of Feline Mammary Carcinomas: A Review of the Literature. Vet. Pathol. 52(1):46-60. https:/doi. org $/ 10.1177 / 0300985814528221$

Range 1: 15 to 844

Score:1179 bits(3050), Expect:0.0, Method:Compositional matrix adjust., Identities:559/838(67\%), Positives:693/838(82\%), Gaps:9/838(1\%)

Query 14 CGNSFSGGQPSSTDAPKAWNYELPATNYETQDSHKAGPIGILFELVHIFLYVVQPRDFPE 73

Sbjct 15 ...TLCL.SR...EGTEVLEL.........K..Y.......... QI.....R......... 74

Query 74 DTLRKFLQKAYESKIDYDKPETVILGLKIVYYEAGIILCCVLGLLFIILMPLVGYFFCMC 133

Sbjct 75 .I...I...

KFDLST..E...N.V.T...I...I.V.I.A......V........CC.GL. 134

Query 134 RCCNKCGGEMHQRQKENGPFLRKCFAISLLVICIIISIGIFYGFVANHQVRTRIKRSRKL 193

Sbjct 135 ........................V.....S.F.............HL.

AQ.EKT... 194

Query 194 ADSNFKDLRTLLNETPEQIKYILAQYNTTKDKAFTDLNSINSVLGGGILDRLRPNIIPVL 253

Sbjct 195 .....R.......GA.AE.S...S..T...E...S..DNVK.L..... HEQ...KV..A. 254 
Query 254 DEIKSMATAIKETKEALENMNSTLKSLHQQSTQLSSSLTSVKTSLRSSLNDPLCLVHPSS 313

Sbjct 255 .D..A..E.........L.V.N...E.KKS.A..NT..SD.. RD.EQ ......M.SAP.VA 314

Query 314 ETCNSIRLSLSQLNSNPELRQLPPVDAELDNVNNVLRTDLDGLVQQGYQSLNDIPDRVQR 373

Sbjct 315 T...N..T.....DD.TNMD...SL.KPI.KI.

DI.Q.N.SS......K.F...EM.EN 374

Query 374 QTTTVVAGIKRVLNSIGSDIDNVTQRLPIQDILSAFSVYVNNTESY-

IHRNLPTLEEYDSY 433

Sbjct 375 ...DIISDV.ST........

ESIGEQI....Q..N.MG.I.D..T..R 434

Query 434 WWLGGLVICSLLTLIVIFYYLGLLCGVCGYDRHATPTTRGCVSNTGGVFLMVGVGLSFLF 493

Sbjct 435

R.....V.C....V..........T.....N....R........I.....A.V...I 494

Query 494 CWILMIIVVLTFVFGANVEKLICEPYTSKELFRVLDTPYLLNEDWEYYLSGKLFNKSKMK 553

Sbjet 495 .....T.......V.......L....QNRK..Q_..........N.KH.... MV...PDIN 554

Query 554 LTFEQVYSDCKKNRGTYGTLHLQNSFNISEHLNINEHTGSISSELESLKVNL-NIFLLGA 612

Sbjct 555 _.........E.K.I...K.E..Y...........A.N..ND-

FQNM...ID..V..DE 614

Query 613 AGRKNLQDFAACGIDRMNY-

DSYLAQTGKSPAGVNLLSFAYDLEAKANSLP-

PGNLRNSLKR 672

Sbjct 615 ..........SFS...AI..NI...

ELS.A.TKG......D...V...H..H.S.KQ...N 674

Query 673 DAQTIKTIHQQRVLPIEQSLST-

LYQSVKILQRTGNGLLERVTRILASLDFAQN-

FITNNTS 732

Sbjct 675 N....R...RSE.I.L...M.SV...I.E..QKSS..GMK..

NT.S...S..D.L.TRI. 734

Query 733 SVIIEETKKYGRTIIGYFEHYLQWIEFSISEKVASCKPVATALDTAVDVFLCSYIIDPLN 792 Sbjct 735 ...V...SQ...N..V....R....

VKI..T..I.A.......................... 794

Query 793 LFWFGIGKATVFLLPALIFA-
Advances in Animal and Veterinary Sciences

VKLAKYYRRMDSEDVYDDVETIPMKNMENGNNGYHKDH 850

Sbjct 795 H............ I.F.RH.

844

>prominin-1 isoform X1 [Felis catus]

Sequence ID: XP_019685284.2 Length: 855

$>$ prominin-1 isoform X1 [Felis catus]

Sequence ID: XP_019685285.2 Length: 855

$>$ prominin-1 isoform X1 [Felis catus]

Sequence ID: XP_019685286.2 Length: 855

Range 1: 15 to 850

Score:1171 bits(3029), Expect:0.0,

Method:Compositional matrix adjust.,

Identities:559/844(66\%), Positives:693/844(82\%),

Gaps:15/844(1\%)

Query 14 CGNSFSGGQPSSTDAPKAWNYELPATNYETQDSHKAGPIGILFELVHIFLYV-

VQPRDFPE 73

Sbjct 15 ...TLCL.SR...EGTEVLEL...................G..

QII....R......... 74

Query 74 DTLRKFLQKAYESKIDYDKPET-

VILGLKIVYYEAGIILCCVLGLLFIILMPLVGYFFCMC 133

Sbjct 75 .I...I...

KFDLST..E...N.V.T...I...I.V.I.A......V.......CC.GL. 134

Query 134 RCCNKCGGEMHQRQKENGPFLRKCFAISLLVICIIISIGIFYGFVANHQVRTRIKRSRKL 193

Sbjct $135 \quad$..............................S.F.............HL.

AQ.EKT... 194

Query 194 ADSNFKDLRTLLNETPEQIKY-

ILAQYNTTKDKAFTDLNSINSVLGGGILDRLRPNIIPVL 253

Sbjct 195 .....R.......GA.AE.S...S..T...E...S..DNVK.L..... HEQ...KV..A. 254

Query 254 DEIKSMATAIKETKEALENMNSTLKSLHQQSTQLSSSLTSVKTSLRSSLNDPLCLVHPSS 313

Sbjct 255 .D..A..E.........L.V.N...E.KKS.A..NT..SD.. RD.EQ .....M.SAP.VA 314

Query 314 ETCNSIRLSLSQLNSNPELRQLPPVDAELDNVNNVLRTDLDGLVQQGYQSLNDIPDRVQR 373

Sbjct 315 T...N..T.....DD.TNMD...SL.KPI.KI. 
DI.Q.N.SS......K.F....EM.EN 374

Query 374 QTTTVVAGIKRVLNSIGSDIDN-

VTQRLPIQDILSAFSVYVNNTESY-

IHRNLPTLEEYDSY 433

Sbjct 375 ...DIISDV.ST........

ESIGEQI....Q..N.MG.I.D..T..R 434

Query 434 WWLGGLVICSLLTLIVIFYYLGLLCGVCGYDRHATPTTRGCVSNTGGVFLMVGVGLSFLF 493

Sbjct 435

R.....V.C....V..........T.....N....R..............A.V...I 494

Query 494 CWILMIIVVLTFVFGANVEKLICEPYTSKELFRVLDTPYLLNEDWEYYLSGKLFNKSKMK 553

Sbjct 495 .....T......V.......L....QNRK..Q............KH.... MV...PDIN 554

Query 554 LTFEQVYSDCKKNRGTYGTLHLQNSFNISEHLNINEHTGSISSELESLKVNL-NIFLLGA 612

Sbjct 555 ..........E.K.I...K.E..Y.......Q...A.N..ND-

FQNM...ID..V..DE 614

Query 613 AGRKNLQDFAACGIDRMNY-

DSYLAQTGKSPAGVNLLSFAYDLEAKANSLP-

PGNLRNSLKR 672

Sbjct 615 ......M..SFS...AI..NI...

ELS.A.TKG......D...V...H..H.S.KQ...N 674

Query 673 DAQTIKTIHQQRVLPIEQSL------STLYQSVKILQRTGNGLLERVTRILASLDFAQNF 726

Sbjct 675 N....R...RSE.I.L...MKYGKAR.SV...I.E.. QKSS..GMK..NT.S...S..D. 734

Query 727 ITNNTSSVIIEETKKYGRTIIGYFEHYLQWIEFSISEKVASCKPVATALDTAVDVFLCSY 786

Sbjct 735 L.TRI....V...SQ...N..V....R....

VKI..T..I.A................... 794

Query 787 IIDPLNLFWFGIGKATVFLLPALIFAVKLAKYYRRMDSEDVYDDVETIPMKNMENGNNGY 846

Sbjct 795 ....M .H..........E.--------....I.F 846

Query $847 \mathrm{HKDH} 850$

Sbjct 847 .RH. 850
$>$ prominin-1 isoform X4 [Felis catus]

Sequence ID: XP_019685292.2 Length: 840

Range 1: 15 to 835

Score:1159 bits(2998), Expect:0.0,

Method:Compositional matrix adjust.,

Identities:553/838(66\%), Positives:686/838(81\%),

Gaps:18/838(2\%)

Query 14 CGNSFSGGQPSSTDAPKAWNYELPATNYETQDSHKAGPIGILFELVHIFLYV-

VQPRDFPE 73

Sbjct 15 ...TLCL.SR...EGTEVLEL............Y.......... QI.....R........ 74

Query 74 DTLRKFLQKAYESKIDYDKPET-

VILGLKIVYYEAGIILCCVLGLLFIILMPLVGYFFCMC 133

Sbjct 75 .I...I...

KFDLST..E.---------.I..I.V.I.A......V........CC.GL. 125

Query 134 RCCNKCGGEMHQRQKENGPFLRKCFAISLLVICIIISIGIFYGFVANHQVRTRIKRSRKL 193

Sbjct 126 ...............................S.F.............HL.

AQ.EKT... 185

Query 194 ADSNFKDLRTLLNETPEQIKY-

ILAQYNTTKDKAFTDLNSINSVLGGGILDRLRPNIIPVL 253

Sbjct 186 .....R.......GA.AE.S...S..T...E...S..DNVK.L..... HEQ...KV..A. 245

Query 254 DEIKSMATAIKETKEALENMNSTLKSLHQQSTQLSSSLTSVKTSLRSSLNDPLCLVHPSS 313

Sbjct 246 .D..A..E.........L.V.N...E.KKS.A..NT..SD.. RD.EQ.....M.SAP.VA 305

Query 314 ETCNSIRLSLSQLNSNPELRQLPPVDAELDNVNNVLRTDLDGLVQQGYQSLNDIPDRVQR 373

Sbjct 306 T...N..T.....DD.TNMD...SL.KPI.KI.

DI.Q.N.SS......K.F....EM.EN 365

Query 374 QTTTVVAGIKRVLNSIGSDIDN-

VTQRLPIQDILSAFSVYVNNTESY-

IHRNLPTLEEYDSY 433

Sbjct 366 ...DIISDV.ST........

ESIGEQI....Q..N.MG.I.D..T..R 425

Query 434 WWLGGLVICSLLTLIVIFYYLGLLCGVCGYDRHATPTTRGCVSNTGGVFLMVGVGLS- 
FLF 493

Sbjct 426

R......V.C....V. T..........R I.....A.V...I 485

Query 494 CWILMIIVVLTFVFGANVEKLICEPYTSKELFRVLDTPYLLNEDWEYYLSGKLFNKSKMK 553

Sbjet 486 .....T.......V.......L....QNRK..Q_............KH.... MV...PDIN 545

Query 554 LTFEQVYSDCKKNRGTYGTLHLQNSFNISEHLNINEHTGSISSELESLKVNL-NIFLLGA 612

Sbjct 546 ..........E.K.I...K.E..Y...........A.N..NDFQNM...ID..V..DE 605

Query 613 AGRKNLQDFAACGIDRMNYDSYLAQTGKSPAGVNLLSFAYDLEAKANSLPPGNLRNSLKR 672

Sbjct 606 .......M..SFS...AI..NI...

ELS.A.TKG......D...V...H..H.S.KQ...N 665

Query 673 DAQTIKTIHQQRVLPIEQSLSTLYQSVKILQRTGNGLLERVTRILASLDFAQNFITNNTS 732

Sbjct 666 N....R...RSE.I.L...M.SV...I.E..QKSS..GMK.. NT.S...S..D.L.TRI. 725

Query 733 SVIIEETKKYGRTIIGYFEHYLQWIEFSISEKVASCKPVATALDTAVDVFLCSYIIDPLN 792 Sbjct 726 ...V..SQ...N..V....R....

VKI..T..I.A......................... 785

Query 793 LFWFGIGKATVFLLPALIFA-

VKLAKYYRRMDSEDVYDDVETIPMKNMENGNNGYHKDH 850

Sbjct 786 H............ E.-------....I.F.RH. 835

$>$ prominin-1 isoform $\mathrm{X} 2$ [Felis catus]

Sequence ID: XP_019685287.2 Length: 849

Range 1: 15 to 838

Score:1157 bits(2992), Expect:0.0, Method:Compositional matrix adjust., Identities:550/824(67\%), Positives:683/824(82\%), Gaps:7/824(0\%)

Query 14 CGNSFSGGQPSSTDAPKAWNYELPATNYETQDSHKAGPIGILFELVHIFLYVVQPRDFPE 73

Sbjct 15 ...TLCL.SR...EGTEVLEL............Y......G..
QI.....R....N.... 74

Query 74 DTLRKFLQKAYESKIDYDKPET-

VILGLKIVYYEAGIILCCVLGLLFIILMPLVGYFFCMC 133

Sbjct 75 .I...I...

KFDLST..E...N.V.T...I...I.V.I.A......V.......CC.GL. 134

Query 134 RCCNKCGGEMHQRQKENGPFLRKCFAISLLVICIIISIGIFYGFVANHQVRTRIKRSRKL 193

Sbjct $135 \quad$.........................V.....S.F.............HL.

AQ.EKT... 194

Query 194 ADSNFKDLRTLLNETPEQIKY-

ILAQYNTTKDKAFTDLNSINSVLGGGILDRLRPNIIPVL 253

Sbjct 195 .....R.......GA.AE.S...S..T...E...S..DNVK.L..... HEQ...KV..A. 254

Query 254 DEIKSMATAIKETKEALENMNSTLKSLHQQSTQLSSSLTSVKTSLRSSLNDPLCLVHPSS 313

Sbjct 255 .D..A..E.........L.V.N...E.KKS.A..NT..SD.. RD.EQ.....M.SAP.VA 314

Query 314 ETCNSIRLSLSQLNSNPELRQLPPVDAELDNVNNVLRTDLDGLVQQGYQSLNDIPDRVQR 373

Sbjct 315 T...N..T.....DD.TNMD...SL.KPI.KI.

DI.Q.N.SS......K.F....EM.EN 374

Query 374 QTTTVVAGIKRVLNSIGSDIDNVTQRLPIQDILSAFSVYVNNTESY-

IHRNLPTLEEYDSY 433

Sbjct 375 ...DIISDV.ST........

ESIGEQI....Q..N.MG.I.D..T..R 434

Query 434 WWLGGLVICSLLTLIVIFYYLGLLCGVCGYDRHATPTTRGCVSNTGGVFLMVGVGLSFLF 493

Sbjct 435

R.....V.C....V..........T.....N....R..............A.V...I 494

Query 494 CWILMIIVVLTFVFGANVEKLICEPYTSKELFRVLDTPYLLNEDWEYYLSGKLFNKSKMK 553

Sbjct 495 .....T.......V.......L....QNRK..Q............KH.... MV...PDIN 554

Query 554 LTFEQVYSDCKKNRGTYGTLHLQNSFNISEHLNINEHTGSISSELESLKVNL-NIFLLGA 612

Sbjct 555 E.K.I....K.E..Y Q..A.N..ND- 
FQNM...ID..V..DE 614

Query 613 AGRKNLQDFAACGIDRMNY-

DSYLAQTGKSPAGVNLLSFAYDLEAKANSLP-

PGNLRNSLKR 672

Sbjct 615 ......M..SFS...AI..NI...

ELS.A.TKG......D...V...H..H.S.KQ...N 674

Query 673 DAQTIKTIHQQRVLPIEQSL------ST-

LYQSVKILQRTGNGLLERVTRILASLDFAQNF

726

Sbjct 675 N....R...RSE.I.L...MKYGKAR.SV...I.E..

QKSS..GMK..NT.S...S..D. 734

Query 727 ITNNTSSVIIEETKKYGRTIIGYFE-

HYLQWIEFSISEKVASCKPVATALDTAVDVFLCSY

786

Sbjct 735 L.TRI....V..SQ...N..V....R....

VKI..T..I.A................... 794

Query 787 IIDPLNLFWFGIGKATVFLLPALIFA-

VKLAKYYRRMDSEDVYDD 830

Sbjct 795 .....M. H. EE 838

S2:

NCBI Multiple Sequence Alignment Viewer, Version 1.20.0

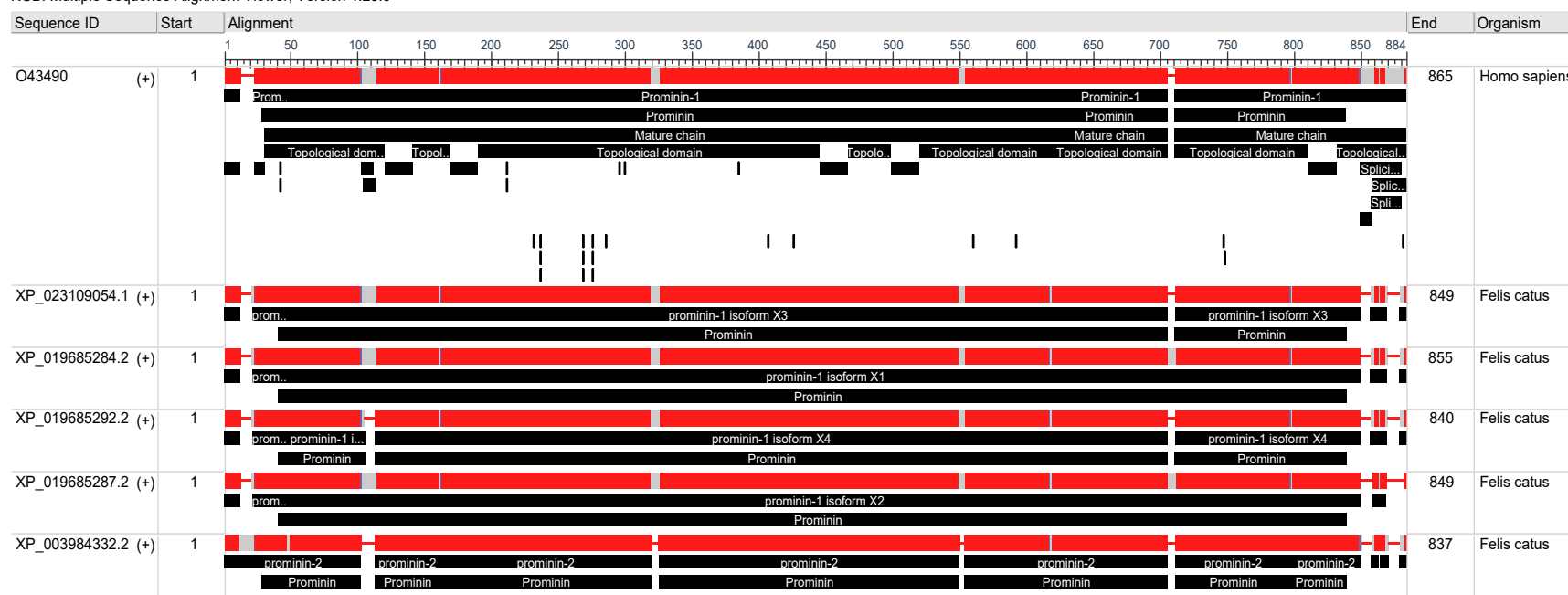

S3:

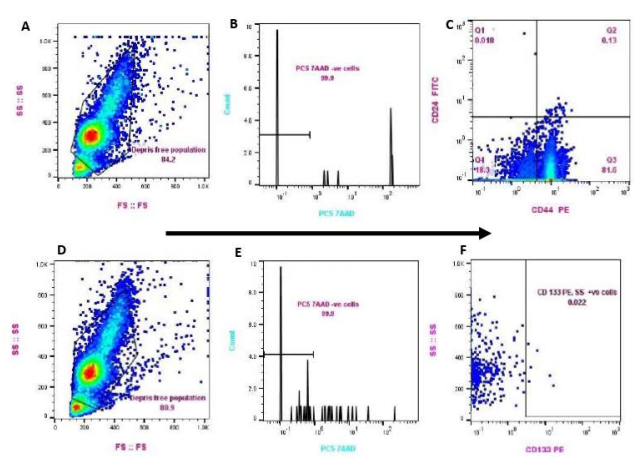

S.3: The applied gating strategy for both $\mathrm{CD} 44^{+} / \mathrm{CD} 24$ combination (A-c) and $\mathrm{CD}_{133^{+}}$cells (D-F). A\&D: Gating to exclude debris, B\&E: Live/Dead gating, C\&F: specific markers gating.

December 2021 | Volume 9 | Issue 12 | Page 2215 